\title{
Combining the rational and relational perspectives of electronic trading
}

\author{
Eduardo Redondo', \\ Elizabeth Daniel ${ }^{2}$ and \\ John Ward ${ }^{3}$ \\ ${ }^{1}$ Universidade Lusofona de Humanidades \\ e Tecnologia, Lisboa, Portugal; ${ }^{2}$ Open University \\ Business School, Milton Keynes, U.K.; ${ }^{3}$ Cranfield \\ School of Management, Cranfield University, \\ Bedford, U.K.
}

Correspondence: Elizabeth Daniel, Open University Business School, Walton Hall, Milton Keynes, U.K.

E-mail: e.m.daniel@open.ac.uk
Received: 4 April 2008

Revised: 8 December 2008

Accepted: 8 December 2008

\begin{abstract}
Many organisations make extensive use of electronic linkages to facilitate their trading exchanges with partners such as suppliers, distributors and customers. This research explores how the use of inter-organisational systems (IOS) both affects, and is affected by, the relationships between trading partners. In doing this, it brings together two existing but distinct perspectives and literatures; the rational view informed by IOS research, and the behavioural or relationship perspective embodied in inter-organisational relationships (IOR) literature. The research was undertaken in the European paper industry by means of six dyadic case studies. The dyads studied covered both traditional electronic data interchange systems and newer e-marketplace environments. A framework was derived from existing literature that integrates the two perspectives of interest. The framework was used to analyse the case studies undertaken and enabled the inter-relationship between IOS use and IOR to be explained.

European Journal of Information Systems (2009) 18, 79-97.

doi: | 0.1057/ejis.2008.6।
\end{abstract}

Keywords: e-trading; inter-organisational systems; inter-organisational relationships

\section{Introduction}

In today's highly competitive, global business environment, most companies realise that the nature and quality of their inter-organisational relationships (IOR), and how these relationships are enabled and developed, are critical to their continued success. Inter-organisational systems (IOS) have become an established means of exchanging information and effecting transactions between partners in most industries. Although there is a recognition that IOS can have an impact on IOR, the inter-relationship between these is not well understood. For example, the emergence of new internet-enabled forms of IOS, such as electronic marketplaces (Kaplan \& Sawhney, 2000; Dai \& Kauffman, 2002) were heralded as a means of organisations finding and building relationships with new trading partners easily and inexpensively. However, given the high closure rates of e-marketplaces, it would appear that such a view of the relationship between IOS and IOR was simplistic and even incorrect (Helper \& McDuffie, 2003).

Given that companies may have a variety of reasons for entering and maintaining IOR, it has been suggested (Dwyer et al., 1987; Jap \& Mohr, 2002) that the multidimensionality of the exchange process can only be captured by including factors from both IOR and IOS perspectives and hence in this study we sought to combine both approaches. In particular, the study explores how, at the level of individual constructs drawn from the IOR and IOS literatures, the use of IOS affects, and is affected by IOR. The work seeks to integrate and extend existing knowledge and hence uses a deductive approach of deriving a proposed 
framework from existing IOS and IOR literatures, which is validated by application to a specific context - the European paper industry. Since both IOS and IOR by definition impact both organisations involved in the partnership, this research adopts a dyadic approach.

The paper commences with a brief review of the theoretical bases employed in the IOS and IOR fields and a summary of previous literature that brings together these two perspectives. A research framework, developed from these literatures is then presented, followed by the methodology adopted for the empirical stage of this work. The framework is then applied to the findings of the case studies. The framework can explain the differing relationship between IOR and IOS found in the cases and it also offers a logical rationale for combining the theoretical bases that, to date, have tended to be considered in isolation. The conclusions and implications of the study are discussed and opportunities for future research are noted.

\section{Theoretical bases of IOR and IOS}

The theoretical bases for IOR studies include Resource Dependency Theory (Pfeffer \& Salancik, 1978) and Social Exchange Theory (SET) (Homans, 1958; Levine \& White, 1961). The former theory proposes that firms rely on other firms for essential resources and will want to minimise this dependence, while wishing to increase the dependence of other firms on them. This brings the notion of coordination and dependency between firms into the consideration of trading relationships. SET, rather than consider exchanges between two organisations, considers exchanges between specific individual actors and characterises these as 'actions contingent on rewarding actions from others' (Blau, 1964). SET therefore suggests that the notions of interpersonal trust and bonds and cooperation should also be included in a consideration of e-trading relationships.

Consistent with these theories, empirical studies (Cunningham, 1980; Ford, 1980; Håkansson, 1980) have noted that, rather than the traditional adversarial perspective, cooperation between trading and exchange partners represents a more accurate view of reality. IOR are conceptualised as dyadic interactions at both the company and individual level with interaction influenced by the atmosphere, a multidimensional construct involving power/dependence, cooperation, expectations, closeness and the environment of the interaction (Håkansson \& Wootz, 1979). Relationship marketing (RM) provides another stream of literature relevant to IOR. As companies form partnerships for the purpose of achieving goals that they could not attain individually (Vlosky \& Wilson, 1997), these relationships are held together by normative as opposed to contractual methods (Weitz \& Jap, 1995).

The IOS literature is again extensive and draws from multiple theoretical bases (Kumar \& Crook, 1999) including Transaction Cost Economics (TCE) (Williamson, 1985) and Agency Theory (Ross, 1973). TCE, which is based upon the notion of rational behaviour, although this is recognised to be bounded in nature (Chiles \& McMackin, 1996), proposes that firms will seek to reduce the transaction or coordination costs incurred in trading with other firms. While in-house production or hierarchical structures (Malone et al., 1987; Clemons et al., 1993) can reduce such costs, for those firms that must engage in trading relationships due to resource dependency, e-trading appears to offer a means of reducing transaction costs (Malone et al., 1987). The cost of each individual transaction will be minimised if set up and ongoing costs of the e-trading link are as low as possible and amortised over as a large number of transactions. Hence TCE suggests high volumes and a breadth or diversity of transactions and increased system-to-system integration will reduce ongoing transaction costs. The principalagent problem that characterises Agency Theory suggests that firms acting as principals will seek to align the interests of their trading partners with their own interests, suggesting the notion of a priori and ongoing expectations of the trading arrangement.

Cunningham \& Tynan (1993) and Fredriksson \& Vilgon (1996) represent some of the earlier attempts at bridging IOR and IOS literatures. The latter authors recognise that e-trading benefits do not originate solely from the use of IOS, 'but arise from interaction with human, organisational, industrial organisation, networking and other competitive aspects' (p. 5). Nidumolu (1995), in a similar manner to Fredriksson \& Vilgon (1996), includes process-related aspects of IOR when considering IOS. Factors relating to efficiency, goal compatibility, domain consensus and norms of exchange are considered to account for the relationship sentiments between companies participating in e-trading. Bensaou (1997) found that 'predictions made by a transaction cost analysis' were supported, however 'relational as well as technological factors must be added to the equation' (p. 120).

\section{A proposed framework from extant literature}

Figure 1 shows the proposed framework, which consists of three dimensions: E-trading Use, Exchange Climate and Performance Satisfaction. E-trading Use is characterised by constructs drawn from IOS (e.g. Iacovou et al., 1995; Masseti \& Zmud, 1996; Hart \& Saunders, 1998). This use is affected by, and affects the IOR, characterised in the model by the Exchange Climate (e.g. Anderson \& Narus, 1990; Morgan \& Hunt, 1994; Wilson, 1995). Finally, as suggested by SET and observed by Vijayasarathy \& Robey (1997), participants must evaluate performance in the relationship favourably for it to survive; hence a Performance Satisfaction dimension is included.

The meta-analysis of buyer-supplier relationships conducted by Wilson (1995) was taken as a starting point of the identification of constructs to include within each dimension of the research framework. From this, constructs that were clearly distinct from each other and were consistent with the theoretical bases adopted were 


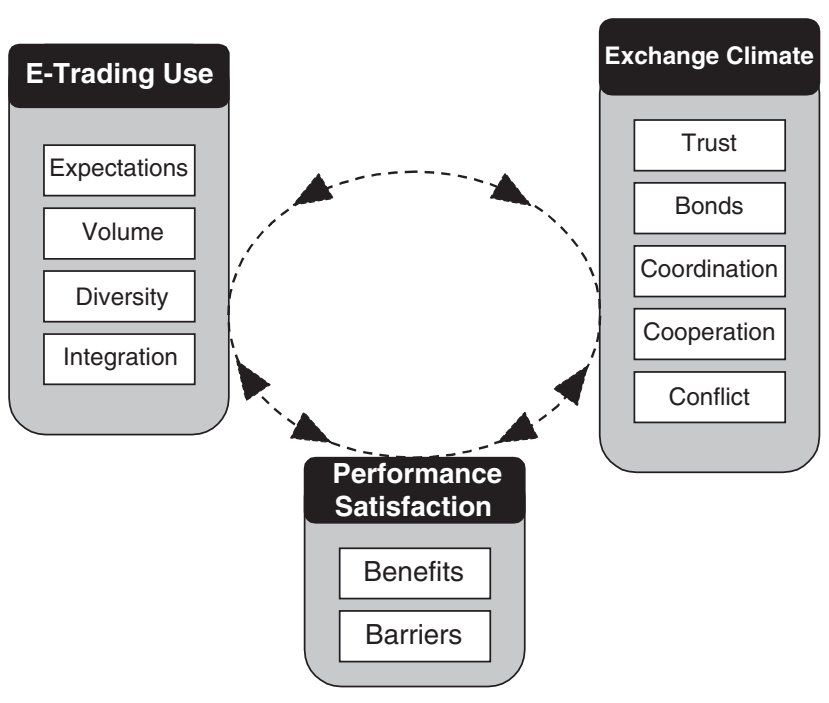

Figure 1 Proposed framework.

identified for inclusion in the initial framework. As with the derivation of most research frameworks, the intention was to be as parsimonious as possible, while retaining the level of detail necessary to differentiate between various instances of the phenomenon being studied. The set of constructs identified was tested during the empirical stage of the study and found to be robust and sufficient. Each of the constructs within the three dimensions of the research framework is discussed in turn below.

That the use of IOS will affect the IOR, and vice versa, identified in the earlier studies that seek to bridge IOR and IOS (e.g. Cunningham \& Tynan, 1993) and that IOS and IOR, both separately and in combination, will affect e-trading Performance Satisfaction (Nidumolu, 1995; Fredriksson \& Vilgon, 1996) suggests feedback loops between the three dimensions of the proposed framework. The three dimensions of the framework are therefore linked by double headed arrows, denoting that influence can occur in either or both directions. A circle is used to join the arrows, to denote the opportunity for vicious and virtuous cycles observed by Gallivan \& Depledge (2003) to arise between the dimensions of the framework.

\section{E-trading Use constructs}

As discussed in the previous section, Agency Theory suggests that companies have certain expectations of their e-trading with partners, which will influence their investment and involvement. This has been confirmed by empirical studies (Iacovou et al., 1995; Allen et al., 2000). An expectations construct is therefore included in the framework. Masseti \& Zmud (1996) use the concept of volume to refer to the proportion of an organisation's total document exchanges with a partner that are handled electronically and diversity as the number of different types of standardised business documents supported by the electronic exchange. Consistent with the efficiency of transactions notion incorporated in TCE, these authors use volume, diversity and system-to-system integration as useful measures of the extent of E-trading Use between organisations.

\section{Exchange Climate constructs}

The literature on marketing channels has commonly found trust to be an important factor in trading relationships (Anderson \& Narus, 1990; Heide \& John, 1990; Cummings \& Bromley, 1996; Zaheer et al., 1998) and its role as a prerequisite for electronic data interchange (EDI) adoption and use has also been noted (e.g., Hart \& Saunders, 1998). A common feature of the development of IOS is the need for various departments or groups from the two firms to work together that may not have previously interacted. Bonds represent this level of 'interconnectedness' between a buyer and seller (Kalafatis, 2000). Included in the construct are structural bonds, which are the elements that create impediments to the termination of the relationship, and social bonds, which are the degree of personal friendships and liking shared by the buyer and seller (Wilson, 1995). Structural bonds incorporate the concepts of dependence and power suggested by Resource Dependency Theory and recognised in other studies (e.g. Fontenot \& Wilson, 1997; Lewin \& Johnston, 1997). Coordination describes the alignment of distinct but interdependent activities (Malone \& Crowston, 1994) and consists of protocols, tasks and decision mechanisms designed to achieve concerted actions between interdependent units.

Cooperation is defined by Anderson \& Narus (1990) as coordinated actions undertaken by firms to achieve superior outcomes with expected reciprocation over time. This construct therefore also incorporates the concept of commitment identified by others (e.g. Anderson \& Weitz, 1990; Wilson \& Vlosky, 1998; Mavondo \& Rodrigo, 2001; Walter et al., 2003). Finally, while conflict is not explicitly recognised in the underlying theoretical bases of this study, it is implicit in them. While it may act to simply reduce the extent of the above constructs, it is explicitly included as a construct in the research framework, since it can provide the opportunity to identify and further explore the sources of conflict and their impact. Explicit recognition of conflict is consistent with studies such as those by Anderson \& Narus (1990) and Nakayama (2003).

\section{Performance Satisfaction constructs}

Vijayasarathy \& Robey (1997) note 'for an inter-organizational relationship to survive, participants must evaluate performance in the relationship favourably and be satisfied that it will achieve individual and collective goals' (p. 76). This notion of performance satisfaction, which is consistent with SET, is captured in the two constructs: benefits and barriers. Benefits represent an overall measure of the cost of establishing and maintaining the e-trading relationship compared to the 
expected outcomes. Included in this construct are both operational and strategic benefits (Suomi, 1988; Fearon \& Philip, 1999). Operational benefits include cost reduction and productivity improvements (e.g. reduced re-keying of information and simplification of order processing tasks), while strategic benefits are associated with increased sales volumes, the development of new products, access to new markets or new organisational capabilities (Reekers \& Smithson, 1994; Mukhopadhyay $\&$ Kekre, 2002).

In a similar approach taken to the notion of conflict, while barriers (Swatman \& Swatman, 1992; Crum et al., 1996) may simply reduce the level of benefits realised, this construct is explicitly recognised within the framework in order to identify the source of barriers limiting the further development of e-trading and explore their impact. Barriers may be internal to the firms, arise from the interaction between them or arise from the external environment.

As described above, earlier studies have suggested that there are influences between IOS and IOR (e.g. Cunningham \& Tynan, 1993; Fredriksson \& Vilgon, 1996). However, no previous study has explored these linkages at the level of individual constructs. By exploring individual constructs, this research provides more specific and actionable understanding of how the performance of e-trading between organisations can be improved and offers a means of addressing the call to combine the economic and behavioural theories of exchanges between firms (Dwyer et al., 1987; Barringer \& Harrison, 2000).

\section{Research methodology}

Exploration of the constructs identified in the research framework required investigation at various levels: technical, organisational and individual and the interactions between these levels. It has been suggested for a full understanding of such complex interactions, case studies are the most appropriate research method (Benbasat et al., 1987; Galliers \& Land, 1987). Such an approach is also consistent with the further development of existing theory (Yin, 2003). The case studies were compiled from retrospective interviews with a number of employees from both partners in each dyad (Kumar et al., 1993; Yin, 2003). Where possible the reliability of data given by informants was triangulated with other sources such as company documents, annual reports, websites and press reports.

Few extant studies have considered how the use of electronic linkages affects relationships in established manufacturing industries and most of these have focussed on a single relationship (Fredriksson \& Vilgon, 1996; Choudhury et al., 1998; El Sawy et al., 1999) or predate the emergence of electronic markets (Barrett \& Konsynski, 1982; Copeland \& McKenney, 1988). Manufacturing industries are often characterised by both long-term IOR and the use of a variety of IOS, including EDI and e-marketplaces. The paper industry provided the potential for a pan-European set of case studies, which demonstrated a range of well-established IOR and different types of IOS.

The leading Western European paper manufacturers and merchants were approached, which represented a sample of 20 firms. Of those that agreed to participate in the study, their customers or suppliers were then contacted to identify instances where dyadic relationships could be studied. Initial telephone interviews were used to ascertain the nature of the e-trading relationships for example, transaction volumes and diversity, percentage of the business transacted electronically - to ensure that evidence regarding the main constructs could be collected. The six dyads chosen were those that represented sufficient variety of relationships and systems for the study and where both parties were willing to provide informed staff to be interviewed.

Each dyad comprised a paper manufacturer and one of its major customers, paper merchants. Table 1 shows basic information about the companies involved in the study (Seller 2 sold to both Buyer 1 and Buyer 2, resulting in six distinct dyadic case studies). The case study companies represent approximately 90\% of the paper sold in Western Europe.

Consistent with other studies of IOR (Kumar et al., 1993), data were collected by means of interviews lasting

Table 1 Case study companies and interviews undertaken

\begin{tabular}{|c|c|c|c|c|c|}
\hline Company & Country & Number of employees** & Turnover (million) ${ }^{\star *}$ & Interview site & No. of interviewees \\
\hline Seller 1 & France & 1050 & $€ 1862.7$ & U.K. & 4 \\
\hline Seller 2 & Finland & 6611 & $€ 10,000$ & Germany, France and U.K. & 2 \\
\hline Seller 3 & Finland & 19,636 & $€ 4651.4$ & U.K. & 1 \\
\hline Seller 4 & Portugal & 2300 & $€ 1000$ & Portugal and U.K. & 2 \\
\hline Seller 5 & South Africa & 16,000 & $€ 3760$ & Belgium and U.K. & 2 \\
\hline Buyer 1 & France & 1100 & $€ 2457.7$ & U.K. & 2 \\
\hline Buyer 2 & Portugal & 700 & $€ 506$ & Germany and Portugal & 3 \\
\hline Buyer 3 & Finland & 2554 & $€ 1392.6$ & U.K. & 1 \\
\hline Buyer 4 & Netherlands & 950 & $€ 450$ & U.K. and the Netherlands & 3 \\
\hline Buyer 5 & Netherlands & 330 & $€ 353$ & U.K. and the Netherlands & 2 \\
\hline
\end{tabular}

** figures confirmed by reference to annual reports and other published information. 
between 1 and $2 \mathrm{~h}$ with individual key informants. Seventeen interviews were undertaken in person at the companies' premises and five were conducted by telephone. Interviewees were selected based on their involvement in and knowledge of the business trading activities or the e-trading systems used or both. An interview guide was developed from the research framework shown in Figure 1, and provided an explicit sampling frame (Miles \& Huberman, 1994) which facilitated comparison across cases. All interviews were semi-structured and were recorded and transcribed and, where necessary, translated into English. A number of follow-up telephone calls were made to confirm or clarify informants' views, particularly when facts presented by dyad informants differed. The software package QSR NVivo was employed to analyse the interview transcripts (Bazeley, 2002; Crowley et al., 2002), with the research framework used to develop the coding structure. In all cases apart from one (dyad \#4, Seller 3 to Buyer 3) at least four people were interviewed. The trading arrangement in dyad \#4 is somewhat different from the others, the firms being part of the same group linked by a Vendor Managed Inventory (VMI) agreement and traded via the Paperhub platform. However, only one informant from each company was available to discuss the trading arrangements and hence some richness of data was lost for some of the constructs. Nevertheless, the case represented a significant variant from the others and was considered important to the study. Details of the company relationships in each dyad, the IT platform used and the interviewees' roles are summarised in Appendix A.
Within-case analysis was undertaken, using the research framework shown in Figure 1. This was followed by cross-case analysis, also using the research framework, where similarities and differences between the IOR and IOS in the six cases were identified.

\section{Case studies}

The following section gives a brief summary of each of the six dyadic case studies. The current technology platform used, its date of adoption and the information exchanged is summarised in Table 2 and information about the constructs in the research framework is given in Table 3. Additional contextual information about each case is provided in Appendix B.

\section{Dyad \#1 (Seller 1 and Buyer 1)}

Perhaps surprisingly given their long history of e-trading, these firms demonstrate one of the lowest levels of engagement with e-trading of the dyads studied. Although they have high volumes of transactions between them, which led to the development of e-trading, they have implemented only a few standard messages $(n=3)$ (low diversity) and resort to manual input of some data and the exchange of Excel files (low integration).

The trust between the companies has been damaged, particularly at Board level, due to the seller having broken the exclusivity deal with the buyer.

The relationship is probably not what it should be. As a company we tend not to get on, because they have their own objectives. It does get in the way when you get exclusive arrangements taken off you and given to others, it does strain relationships. (Purchasing Manager in Buyer 1)

Table 2 Technology platform, year of adoption and information exchanged

\begin{tabular}{|c|c|c|c|c|c|c|}
\hline$D Y A D \#$ & 1 & 2 & 3 & 4 & 5 & 6 \\
\hline Technology & $E D I$ & $\mathrm{PH}$ & $E D I$ & VMI on $\mathrm{PH}$ & $\mathrm{PH}$ & $\mathrm{PH}$ \\
\hline Year of adoption & 1986 & 2002 & 1986 & 2002 & 2004 & 2002 \\
\hline Order entry & * & $\sqrt{ }$ & * & & $\sqrt{ }$ & $\sqrt{ }$ \\
\hline Order status & & $\sqrt{ }$ & w & & $\sqrt{ }$ & $\sqrt{ }$ \\
\hline Order acknowledgement & * & $\sqrt{ }$ & * & & $\sqrt{ }$ & $\sqrt{ }$ \\
\hline Order history & & & w & & & w \\
\hline Order amendments & & $\sqrt{ }$ & & & $\sqrt{ }$ & $\sqrt{ }$ \\
\hline Invoice & * & $\sqrt{ }$ & * & & $\sqrt{ }$ & $\sqrt{ }$ \\
\hline Stock levels & w & $\bullet$ & w & $\bullet$ & $\bullet$ & $\bullet$ \\
\hline Delivery notes & & $\sqrt{ }$ & * & $\bullet$ & $\bullet$ & $\sqrt{ }$ \\
\hline Production plan & & $\sqrt{ }$ & w & & $\bullet$ & $\sqrt{ }$ \\
\hline Demand forecast & $\bullet$ & w & $\bullet$ & $\bullet$ & $\bullet$ & w \\
\hline Sales plan/budget sales & & $\bullet$ & $\bullet$ & & $\bullet$ & $\bullet$ \\
\hline Stock consumption & & & & $\sqrt{ }$ & & \\
\hline Standard messages ( $*$ or $\sqrt{ }$ only) & 3 & 7 & 4 & 1 & 5 & 7 \\
\hline Total messaging formats & 5 & 10 & 10 & 4 & 10 & 11 \\
\hline
\end{tabular}

*, standard EDI message; $\sqrt{ }$, standard PaperHub message.

-, Excel file; w, secure web page.

$\mathrm{PH}=$ PaperHub. 
Table 3 Summary of constructs within case studies

\begin{tabular}{|c|c|c|c|c|}
\hline $\begin{array}{l}\text { Dimension/ } \\
\text { construct }\end{array}$ & & Dyad \#1 & Dyad \#2 & Dyad \#3 \\
\hline \multirow[t]{4}{*}{ E-trading Use } & Expectations & $\begin{array}{l}\text { Initial focus on costs and } \\
\text { administrative savings }\end{array}$ & $\begin{array}{l}\text { Ability to cooperate more closely with } \\
\text { partners in order to achieve mutual } \\
\text { strategic benefits }\end{array}$ & $\begin{array}{l}\text { Mainly cost reduction } \\
\text { focussed }\end{array}$ \\
\hline & Volume & $\begin{array}{l}\text { High volume of business between } \\
\text { firms in same group led to } \\
\text { development of e-trading }\end{array}$ & $\begin{array}{l}\text { High volumes led to development of } \\
\text { e-trading }\end{array}$ & $\begin{array}{l}\text { High volume recognised as } \\
\text { pre-condition to e-trading } \\
\text { development }\end{array}$ \\
\hline & Diversity & $\begin{array}{l}\text { Low }- \text { few standard messages } \\
(n=3)\end{array}$ & $\begin{array}{l}\text { High - high number of standard } \\
\text { messages }(n=7) \text { for transactional } \\
\text { purposes, with non-standard ones for } \\
\text { forecasting and planning }\end{array}$ & $\begin{array}{l}\text { Low - few standard } \\
\text { messages }(n=4)\end{array}$ \\
\hline & Integration & $\begin{array}{l}\text { Integration of standard EDI messages } \\
\text { only, with need for some manual } \\
\text { input, and non-systematic exchange } \\
\text { of Excel files }\end{array}$ & $\begin{array}{l}\text { High - full system integration for } \\
\text { e-trading with additional shared } \\
\text { databases to support joint business } \\
\text { initiatives }\end{array}$ & $\begin{array}{l}\text { Low - due to Buyer 2's } \\
\text { internal systems limitations }\end{array}$ \\
\hline \multirow[t]{5}{*}{$\begin{array}{l}\text { Exchange } \\
\text { Climate }\end{array}$} & Bonds & $\begin{array}{l}\text { Strained at higher level, but } \\
\text { acceptable at operational levels }\end{array}$ & $\begin{array}{l}\text { Increased contacts across } \\
\text { departments - both operational and } \\
\text { strategic/business development staff } \\
\text { in regular cooperation }\end{array}$ & $\begin{array}{l}\text { Based on personal and } \\
\text { local knowledge }\end{array}$ \\
\hline & Trust & $\begin{array}{l}\text { Low, due to factors outside } \\
\text { e-trading (exclusivity deal) }\end{array}$ & $\begin{array}{l}\text { Inter-organisational trust recognised } \\
\text { as prerequisite for relationships to } \\
\text { develop, but inter-personal trust } \\
\text { enhanced as a consequence of } \\
\text { e-trading }\end{array}$ & $\begin{array}{l}\text { Reduced due to buyer } \\
\text { still viewing secrecy as } \\
\text { important }\end{array}$ \\
\hline & Coordination & $\begin{array}{l}\text { Basic order processing and } \\
\text { maintenance of EDI link }\end{array}$ & $\begin{array}{l}\text { Additional coordination above basic } \\
\text { order processing, for example, } \\
\text { coordination of logistic activities }\end{array}$ & $\begin{array}{l}\text { Basic order processing and } \\
\text { maintaining EDI link }\end{array}$ \\
\hline & Cooperation & No joint initiatives & $\begin{array}{l}\text { Reinvestment of savings into } \\
\text { specific programmes to promote } \\
\text { cooperation and sharing of } \\
\text { resources, for example, Joint } \\
\text { Process Initiative }\end{array}$ & No joint initiatives \\
\hline & Conflict & $\begin{array}{l}\text { Low on transactional issues due } \\
\text { to e-trading removing errors that } \\
\text { were previously a source of } \\
\text { conflict, but strained relationship due } \\
\text { to issues outside electronic trading }\end{array}$ & None at present & $\begin{array}{l}\text { Disagreement as to which } \\
\text { IT platform to expand } \\
\text { electronic link }\end{array}$ \\
\hline \multirow[t]{3}{*}{$\begin{array}{l}\text { Performance } \\
\text { Satisfaction }\end{array}$} & $\begin{array}{l}\text { Benefits - } \\
\text { operational }\end{array}$ & $\begin{array}{l}\text { Cost savings from improved } \\
\text { administration and stock level } \\
\text { reduction }\end{array}$ & $\begin{array}{l}\text { Cost savings in back office } \\
\text { functions, plus lead time and stock } \\
\text { level reductions }\end{array}$ & Administrative savings \\
\hline & $\begin{array}{l}\text { Benefits - } \\
\text { strategic }\end{array}$ & None & $\begin{array}{l}\text { Change to proactive roles } \\
\text { performed by sales people } \\
\text { resulting in increase in sales } \\
\text { volume plus improved service } \\
\text { due to shared logistics }\end{array}$ & None \\
\hline & Barriers & $\begin{array}{l}\text { Breaking of exclusivity deal } \\
\text { damaged inter-personal trust }\end{array}$ & No significant barriers identified & Buyer 2 limited resources \\
\hline
\end{tabular}


Table 3 Continued

\begin{tabular}{|c|c|c|c|c|}
\hline & & Dyad \#4 & Dyad \#5 & Dyad \#6 \\
\hline \multirow[t]{4}{*}{ E-Trading use } & Expectations & $\begin{array}{l}\text { Achieve cost savings and improve } \\
\text { supply-chain efficiencies }\end{array}$ & $\begin{array}{l}\text { Cost and administrative savings to } \\
\text { streamline business operations, } \\
\text { with potential for supply-chain } \\
\text { transparency; higher expectations } \\
\text { due to starting with PaperHub } \\
\text { rather than EDI }\end{array}$ & $\begin{array}{l}\text { Cost savings and } \\
\text { relationship improvement }\end{array}$ \\
\hline & Volume & $\begin{array}{l}\text { High - high volume was important } \\
\text { factor for choice of partner, along } \\
\text { with historic relationship between } \\
\text { the companies }\end{array}$ & $\begin{array}{l}\text { High - volume of transactions as } \\
\text { important factor for partner choice, } \\
\text { along with prior experience in } \\
\text { electronic trading }\end{array}$ & $\begin{array}{l}\text { High volume was } \\
\text { important prerequisite, } \\
\text { along with technological } \\
\text { capability }\end{array}$ \\
\hline & Diversity & Low - but due to VMI arrangement & $\begin{array}{l}\text { Medium - number of standard } \\
\text { messages }(n=5)\end{array}$ & $\begin{array}{l}\text { High number of standard } \\
\text { messages developed } \\
(n=7)\end{array}$ \\
\hline & Integration & $\begin{array}{l}\text { Medium - no manual input of data } \\
\text { but some exchange of Excel files }\end{array}$ & $\begin{array}{l}\text { Medium - integration of standard } \\
\text { messages and files but, at present, } \\
\text { orders still require manual approval }\end{array}$ & $\begin{array}{l}\text { High - direct integration } \\
\text { of standard messages and } \\
\text { also some shared } \\
\text { applications }\end{array}$ \\
\hline \multirow[t]{5}{*}{$\begin{array}{l}\text { Exchange } \\
\text { Climate }\end{array}$} & Bonds & $\begin{array}{l}\text { Multiple inter-departmental contacts } \\
\text { due to electronic trading }\end{array}$ & $\begin{array}{l}\text { Increase in layers of inter-company } \\
\text { contact }\end{array}$ & $\begin{array}{l}\text { Historic personal relations } \\
\text { at operational level, } \\
\text { improved with electronic } \\
\text { link implementation }\end{array}$ \\
\hline & Trust & $\begin{array}{l}\text { High - due to historic relationship } \\
\text { and VMI agreement which is working } \\
\text { well }\end{array}$ & $\begin{array}{l}\text { Growing level of partner trust from } \\
\text { top down }\end{array}$ & $\begin{array}{l}\text { High trust due to past } \\
\text { history of transactions }\end{array}$ \\
\hline & Coordination & $\begin{array}{l}\text { High - due to need to replenish } \\
\text { stocks by Seller } 3 \text { under VMI } \\
\text { agreement }\end{array}$ & At an operational level & $\begin{array}{l}\text { High level of coordination } \\
\text { across multiple depart- } \\
\text { ments, for example, IT, } \\
\text { planning, logistics, } \\
\text { marketing and purchasing }\end{array}$ \\
\hline & Cooperation & At a commercial and marketing level & $\begin{array}{l}\text { At a marketing level and for } \\
\text { PaperHub standards }\end{array}$ & $\begin{array}{l}\text { Reinvestment of savings } \\
\text { and freed resources into } \\
\text { specific relationship }\end{array}$ \\
\hline & Conflict & None at present & None at present & None at present \\
\hline \multirow[t]{3}{*}{$\begin{array}{l}\text { Performance } \\
\text { Satisfaction }\end{array}$} & $\begin{array}{l}\text { Benefits - } \\
\text { operational }\end{array}$ & $\begin{array}{l}\text { Administrative cost savings and stock } \\
\text { level reduction }\end{array}$ & $\begin{array}{l}\text { Decrease in manual work and } \\
\text { reduction in errors }\end{array}$ & $\begin{array}{l}\text { Cash flow and back office } \\
\text { savings in administrative } \\
\text { functions }\end{array}$ \\
\hline & $\begin{array}{l}\text { Benefits - } \\
\text { strategic }\end{array}$ & $\begin{array}{l}\text { Seller benefits from buyer's improved } \\
\text { service levels and closer cooperation } \\
\text { (seller uses power to treat buyer as } \\
\text { a dedicated merchant) }\end{array}$ & $\begin{array}{l}\text { Business refocus from stock ordering } \\
\text { to indent and changing roles of staff, } \\
\text { but longer-time frame needed for } \\
\text { benefits to materialise }\end{array}$ & $\begin{array}{l}\text { Improved customer service } \\
\text { with more proactive staff, } \\
\text { resulting in volume } \\
\text { growth, particularly of } \\
\text { indent business }\end{array}$ \\
\hline & Barriers & $\begin{array}{l}\text { Uneven power distribution between } \\
\text { buyer and supplier prevents true } \\
\text { collaboration }\end{array}$ & Limitations of seller's IT systems & No significant barriers \\
\hline
\end{tabular}


The level of commitment to e-trading is also hampered by disagreement as to which IT platform to use in the future. Both companies have only achieved a limited number of operational benefits, mainly associated with administrative efficiency improvements and cost savings, and reductions in stock holdings. However, Seller 1 believed they had gained from e-trading.

It's allowed us to restructure and to reduce cost ... people have been freed up and can be more proactive - chasing business and looking for new business. (Customer Services Manager in Seller 1)

\section{Dyad \#2 (Seller 2 and Buyer 1)}

These two firms show one of the highest levels of engagement with e-trading among the case studies, indicated by their large volumes of transactions, number of standard message types developed $(n=7)$ (high diversity) and their fully integrated systems and shared databases (high integration).

The firms exhibit high degrees of coordination, cooperation and commitment. This is demonstrated by, for example, sharing of production planning and sales forecasting and joint haulage planning.

Every month we do a forecast in our own forecast system. Buyer 1 is the only company to have access to our forecast. (Customer Services Manager in Seller 1)

They have also undertaken joint business development initiatives arising as a result of adopting e-trading.

What the link did was freed up people to get to know each other. The result of that was that we started something called the 'Joint Process Initiative' which is where we both go out and try and find business for each other. (Customer Services Manager in Seller 2)

This extensive use of e-trading has resulted in significant strategic as well as operational benefits. In addition to cost savings in administration and inventories, lead times have been reduced and both have seen increases in trading volumes. Both organisations view their investment in PaperHub as a demonstration of the commitment to e-trading with each other.

\section{Dyad \#3 (Seller 2 and Buyer 2)}

Together with dyad \#1, dyad \#3 shows one of the lowest levels of engagement with e-trading among the cases studied. While the volume of transactions was sufficiently high to warrant the development of e-trading, the number of message types developed is low $(n=4)$ (low diversity) and integration is low due to limitations of Buyer 2's internal systems. Future options are also limited due to the implementation of a new group-wide ERP system, which reduced the resources available for further e-trading development.

The Exchange Climate is strongly influenced by the geographic location and proximity of the firms involved. Bonds and trust have been established and continue due to local market presence, knowledge and particular individuals.

Purchasing decisions are made based on trust in people. And it's not just trust, it's even this local link. You tend to say that you centralise everything in Hamburg and you trade from there - but we don't really, because this is a local [south German] business. (General Manager in Buyer 2)

The use of e-trading has produced administrative efficiencies and inventory reductions for both parties, but to date no strategic benefits. The level of commitment to etrading is hampered by the inability of the buyer to invest further in e-trading development.

\section{Dyad \#4 (Seller 3 and Buyer 3)}

The volume of trading in this dyad is very high, which led to the development of e-trading, but the number of message types developed is low due to the VMI arrangement these firms have in place. While no manual input is required for data exchange, some data are passed via Excel files (medium integration). Interestingly, while all other dyads show a positive relationship between diversity and integration, due to the reduced number of messages used in VMI, this dyad is not consistent with that pattern, reinforcing the need to include both diversity and integration in the E-trading Use construct.

The Exchange Climate is characterised by the high level of dependence of the buyer on the seller, since the seller's products represent a significant proportion of its sales. The VMI arrangement between the firms further increases such dependence, with the seller being responsible for replenishing the buyer's stock. As with other dyads, personal contact at a sales desk level has reduced following the use of e-trading, but it has resulted in multiple layers of contact across departments. Although there is a mutual commitment to achieving efficiency improvements from e-trading, the seller uses its power in the relationship to relegate the buyer to the role of the company's distributor. As a result the seller has realised more benefits, mainly administrative and inventory savings, than the buyer and although both agree that operational benefits have accrued and relationships have become closer, strategic benefits have not yet been realised.

It's related to e-trading - there is deeper cooperation between the companies and it improved the understanding of the processes. (Supply Chain \& IT Manager - in Buyer 3)

\section{Dyad \#5 (Seller 4 and Buyer 4)}

As with the other dyads, the high volume of transactions justified the development of e-trading. However, the number of standard message types developed $(n=5)$ is more than dyads \# 1 and \#3 but less than dyads \#2 and \#6. The level of integration also lies between these pairs of 
dyads; while no manual input of data exchanged is required, manual approval for orders is still needed.

We do not have shared databases, we only exchange messages. (e-Trading Project Manager in Buyer 4)

Both companies' financial investment in the PaperHub joint venture and a sense of shared objectives has contributed to a high level of partner trust as well as increased the dependency on one another. This increased 'lock-in' is recognised by the seller.

The intention of e-trading is to lock in the customer; naturally that's the intention. (Production Planning Manager in Seller 4).

Coordination has increased with the use of e-trading, particularly at an operational level, resulting in administrative cost savings and improved service lead times. Cooperation has recently also included joint work on establishing PaperHub's technical standards. The companies exhibit a growing commitment towards each other but so far have achieved mainly operational efficiency and cost saving benefits. However, potential strategic benefits have been identified by refocusing the businesses from stock ordering to higher margin indent business and they expect this to yield increased profits for both parties in the future.

\section{Dyad \#6 (Seller 5 and Buyer 5)}

E-trading Use in this dyad is similar to that of dyad \#2, in terms of volume, diversity and level of integration. In particular, in addition to fully integrated e-trading systems, the firms share some applications for activities such as demand planning and forecasting. The sales plan from Buyer 5 is used by Seller 5 to automatically adjust stock levels and production plans without any manual intervention.

Participating in the pilot implementation of the PaperHub e-marketplace and also working subsequently to develop the standards and processes for this marketplace has helped these two firms to become much closer and develop inter-personal bonds and trust.

Because we have had to sit down and talk about each other's processes we've got closer together, both personally and from a business point of view there is a better understanding of what each other's needs are. (IT Implementation Manager in Buyer 5)

In addition to cost reductions and cash flow improvements, both companies have also achieved strategic benefits from their e-trading, through both systems integration and redeploying the staff released to improve and extend customer services, which has increased business volumes.

I actually believe we've gained substantial benefit. Not just us, but the customer as well. We started this endeavour and we will streamline and integrate ourselves more in the future. (Customer Services Manager in Seller 5).

\section{Cross case analysis}

Table 3 suggests that while it was necessary for both partners within a dyad to have consistent expectations from their e-trading, there was a range of expectations across the dyads. Dyads \#1 and \#3 had rather simple expectations of cost savings from administrative efficiencies, whereas dyads \#2 and \#6 had expectations of strategic benefits and relationship improvements. Consistent with extant studies (Iacovou et al., 1995; Masseti \& Zmud, 1996), the data shown in Table 3 suggest a sufficient volume of transactions and level of trust between partners appeared to be a pre-condition to establishing the e-trading link. In contrast, diversity and integration appear to be important in differentiating E-trading Use within the dyads, with dyads \#1 and \#3 showing the lowest use and dyads \#2 and \#6 the highest. Table 3 also suggests varying levels of the Performance Satisfaction dimension across the dyads, particularly according to the benefits realised. Consistent with their more limited expectations, dyads \#1 and \#3 have realised the least (purely operational benefits) and dyads \#2 and \#6, the most (both operational and strategic benefits). These differences suggest three groupings of the dyads that are discussed below.

As noted above, dyads \#1 and \#3 show the lowest level of E-trading Use and benefits realised. Trust is also low, but for reasons outside the use of e-trading. In neither dyad have further initiatives enabled by e-trading been pursued nor can agreement be reached on whether or not to move to a new e-trading platform. Although these are the only two dyads still using EDI, it does not appear that the platform alone is preventing further development. Factors, such as strained relationships between the firms and the resultant lack of trust in combination with the limited benefits achieved so far appear more important.

In contrast, dyads \#4 and \#5 have achieved more benefits from e-trading than dyads \#1 and \#3. In both dyads \#4 and \#5 there is significant integration of transactional messages creating mutual dependence, enabled by the high levels of trust between the trading partners. Both dyads use PaperHub, but both have reservations about the transaction costs and its future. Dyad \#5 has now seen opportunities for achieving more strategic benefits, although few have been realised so far. However, the mutual satisfaction with the operational benefits has increased the commitment to develop the e-trading relationship further in the future.

Finally, dyads \#2 and \#6 show the highest levels of use in terms of both standard messages and additional information exchanged, which is highly integrated with the buyer and seller systems in each dyad. They also report the highest level of overall benefits achieved, including strategic benefits that have led to increased sales volumes. The resulting increased mutual dependence has led to other collaborative initiatives and a strong commitment to further investment in developing 
the partnerships. In the case of dyad \#2 this is seen as a defence against further disintermediation in the industry.

While the dyads trading via EDI have achieved lower levels of benefits than those trading via PaperHub, the finding that there was a variation of benefits across the dyads trading over this e-marketplace suggests that the platform adopted alone does not explain the benefits achieved by the partners. Dyads with similar levels of E-Trading Use also show differing levels of benefits realised (dyads \#4 and \#5), suggesting that the effective use of e-trading within a relationship relies on attributes to those included in E-Trading Use dimension alone. As will be discussed in the following section, examination of the detailed attributes in the Exchange Climate and Performance Satisfaction dimensions suggest that these play a determining role in increasing the use of e-trading between partners and explain why some organisations remain at a fairly basic use of e-trading, while others progress further.

\section{Synthesised findings}

The following section uses the research framework to consider each of the three different levels of E-trading Use and Performance Satisfaction observed in the case studies, and how these affect and are affected by the
Exchange Climate. In the conclusions to the paper we then consider how existing theories can explain why some organisations develop their e-trading relationships to achieve significant strategic benefits, whereas others do not.

\section{Operational development phase}

The basic or lowest level of e-trading is demonstrated by dyads \#1 and \#3. Consistent expectations between partners and, as identified in earlier studies (e.g. Sabherwal \& Vijayasarathy, 1994), a significant volume of transactions and trust appear to be important antecedents to establishing e-trading. At this stage inter-organisational trust, rather than inter-personal trust is important. Expectations, volume and inter-organisational trust are therefore shown as preconditions to the establishment of an electronic trading link in Figure 2.

The use of e-trading starts with basic transactional messages and limited inter-company integration. This was found to reduce the need for human intervention, particularly at the sales desk functions of the sellers and the purchasing or procurement functions of the buyers, which results in reduced inter-personal contact at these levels. At the same time, given the increased ability to coordinate activities, a number of previously separate functions such as IT, logistics and dispatch are brought into closer contact.

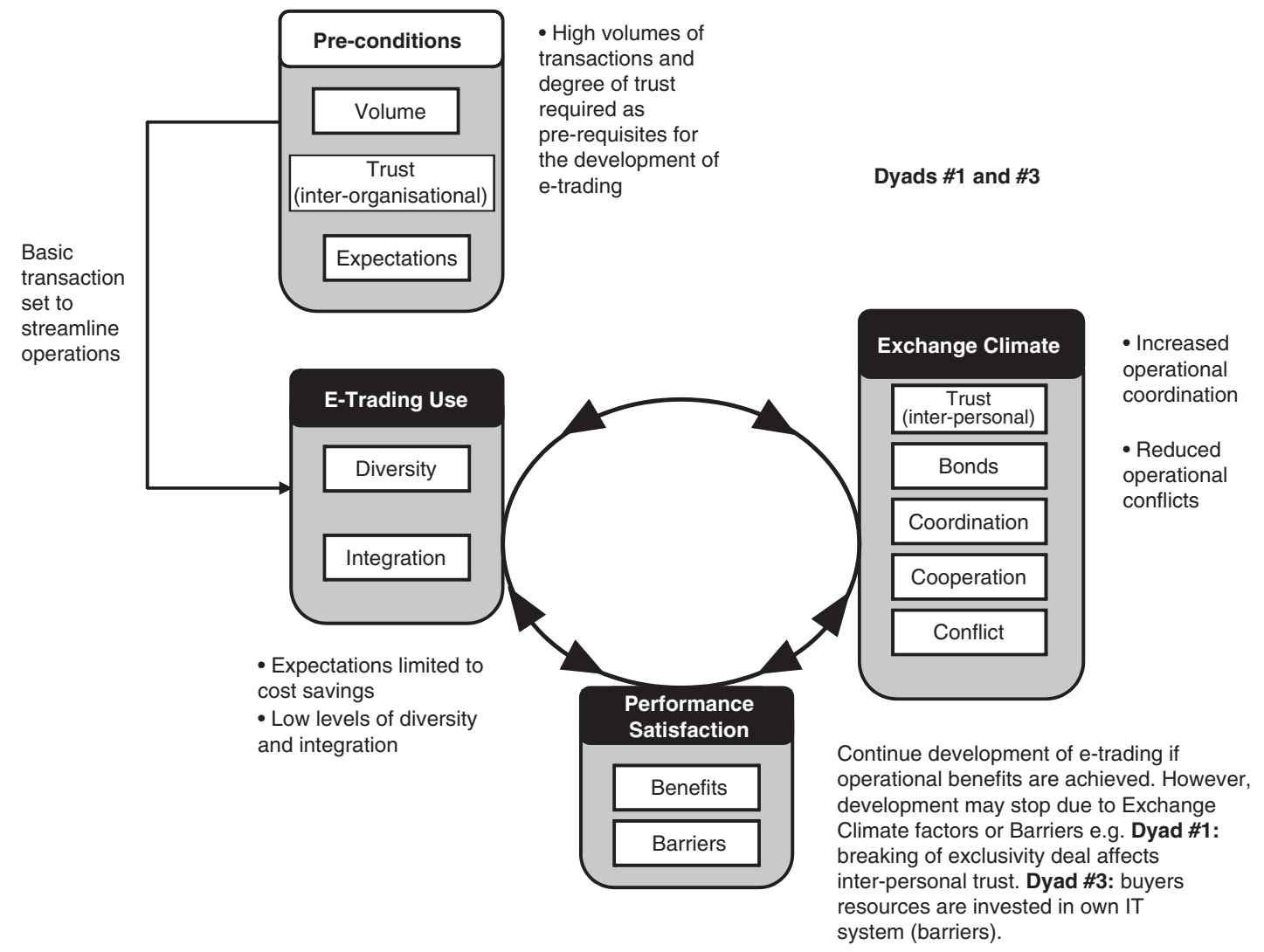

Figure 2 Operational development phase. 
With this use of the e-trading link, companies aim to achieve internal operational improvements by streamlining the transactional aspects of their existing business relationship. This first level we call the 'Operational Development' phase and it is depicted in Figure 2. In our study, this phase is associated with traditional EDI links, which were typically initiated and financially supported by sellers. In this phase, the electronic link contributes to improve the coordination of activities but has no influence on the level of cooperation.

The benefits realised from this initial phase of e-trading are then evaluated, comparing results with initial expectations. As time passes each partner engages in a sense-making process regarding the cause of any variance from target levels, creating a feedback loop across the various dimensions of the framework. When deviations are observable and attributed to the partners' own actions, the feedback loop will be affected (Gallivan \& Depledge, 2003). For example, the removal of an exclusivity deal between the trading companies in the case of dyad \#1 influenced the feedback loop through an effect on bonds (at the board level) and trust. In the case of dyad \#3, the focus of one trading partner on developing its own internal systems and lack of interest in investing in the e-trading link also affected the feedback loop through the cooperation construct.

\section{Operational cooperation phase}

Through the continuing use of e-trading, the feedback loop can start a virtuous cycle (Gallivan \& Depledge, 2003) that enhances the Exchange Climate. The realisation of each company's internal operational benefits can lead trading partners to agree on a number of shared operational expectations about the electronic relationship, and to a decision to share the investment required to further enhance their trading link. A number of the dyads (\#2, \#4, \#5, \#6) followed this route when a decision was made to participate in the PaperHub joint-venture. This led to cooperation at an operational level via the working groups responsible for setting the standards to be used, and an increase in the diversity of messaging formats and levels of integration between the companies. We term this increased level of e-trading the 'Operational Cooperation' phase. Figure 3 shows that the level of operational cooperation between the companies increases and the level of transactional conflicts reduce, when compared with the previous phase.

At this level, the use of e-trading contributes to establish multiple levels of contact across the partners.

This type of relationship building is not reliant on one person. Within the individual merchant, the responsible people in IT and in Supply Chain have each put together a team, and the same thing happens at the mill and these teams get to know each other as they work together. (Supply Chain and IT Manager in Buyer 3)

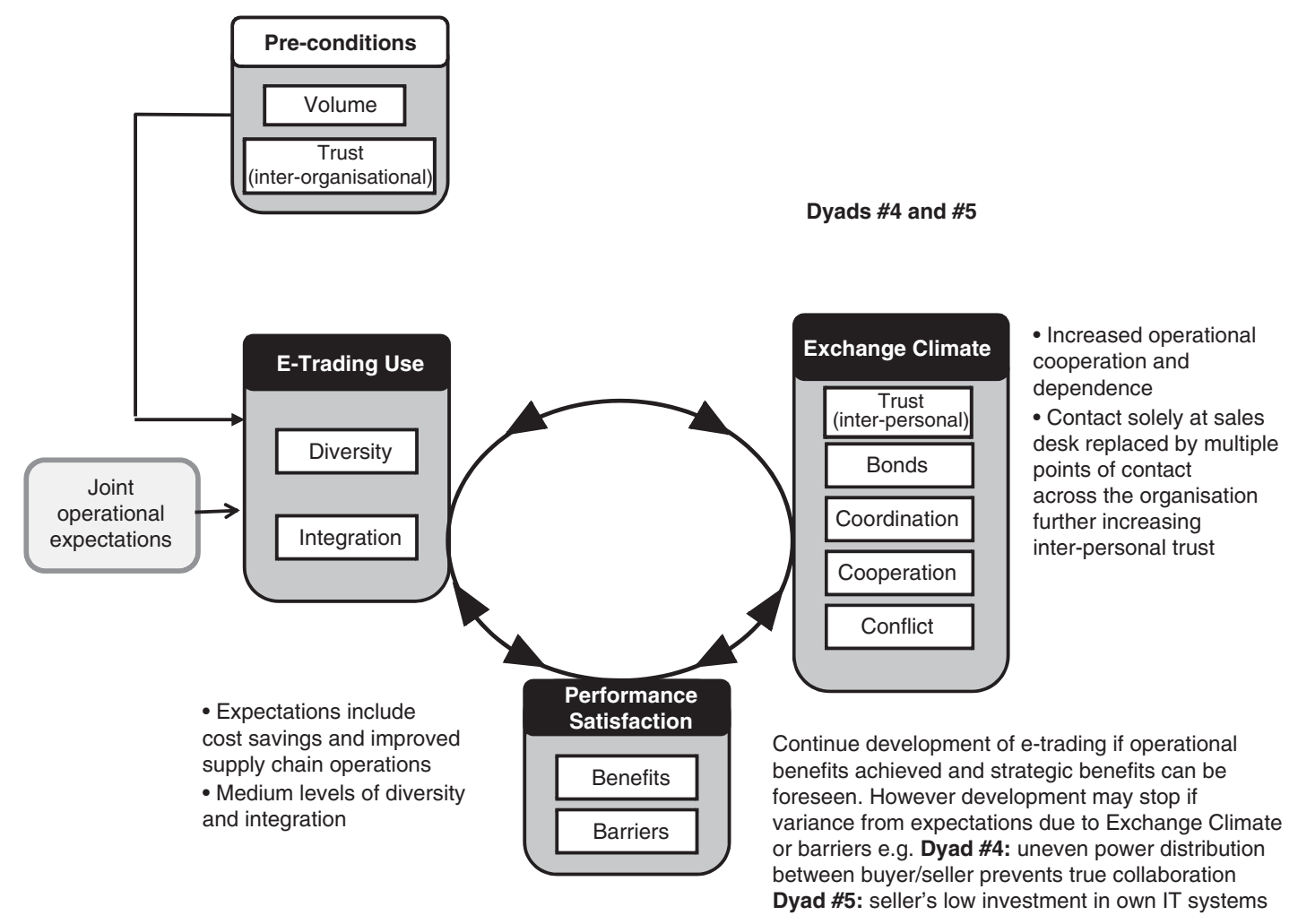

Figure 3 Operational cooperation phase. 
E-trading also helps to increase both trading partners' sense of objective sharing (Chatfield \& Yetton, 2000). With this more favourable Exchange Climate, a closer match between each partners' achieved and expected benefits is established. However, the continuity of the virtuous feedback loop can only be sustained if the constructs within the Exchange Climate support the increased level of cooperation and objective sharing. For example, companies in dyads \#4 and \#5 have increased the coordination of activities between themselves, realising benefits from e-trading that have matched their operational level expectations. However, the virtuous cycle appears to remain stalled at Operational Cooperation for companies in dyad \#4 as the seller is using the PaperHub trading link to accentuate its hierarchical power over the buyer, while in dyad \#5 the seller is deferring further investment in use of the e-marketplace in order to improve its own internal IT systems.

\section{Strategic alliance phase}

Dyads \#2 and \#6 illustrate how the virtuous cycle in the previous phase can be developed further by the setting of joint strategic objectives. These objectives are consistent with the original expectations of these dyads, which were focussed on the realisation of strategic benefits and relationship improvement. These allow trading partners to move from a mechanism that achieves more efficient coordination and cooperation at an operational level, to a platform that enables and reinforces a sense of objective sharing across various departments or groups within the organisations, further enhancing their Exchange Climate. At this level, trading partners mutually acknowledge their inter-dependency, increasingly cooperating on previously unrelated activities. We have termed this the 'Strategic Alliance' phase (Figure 4).

Through the continuing effect of this virtuous feedback loop on the Exchange Climate, companies in dyads \#2 and \#6 further developed their trading relationship. Savings due to e-trading were invested back into the same relationship, rather than to other relationships or to all relationships, in order to improve it further. At this level conflicts and barriers are minimised and companies achieve a number of strategic benefits of e-trading including realising growth in volumes of transactions and increased sales of higher margin indent business.

It is interesting to note that Seller 2 is in the 'Operational Development' phase in its relationship with Buyer 2 (dyad \#3), but in the 'Strategic Alliance' phase in dyad \#2, trading with Buyer 1. First, it shows that an organisation can, and probably will, be at different e-trading phases with different partners at the same time. In this, case Seller 2 is trading via different platforms with the two buyers, but this does not fully explain the significant differences in its relationships in the two dyads. It is the reluctance of Buyer 2 to invest further in e-trading, due to other IT priorities, that has stopped

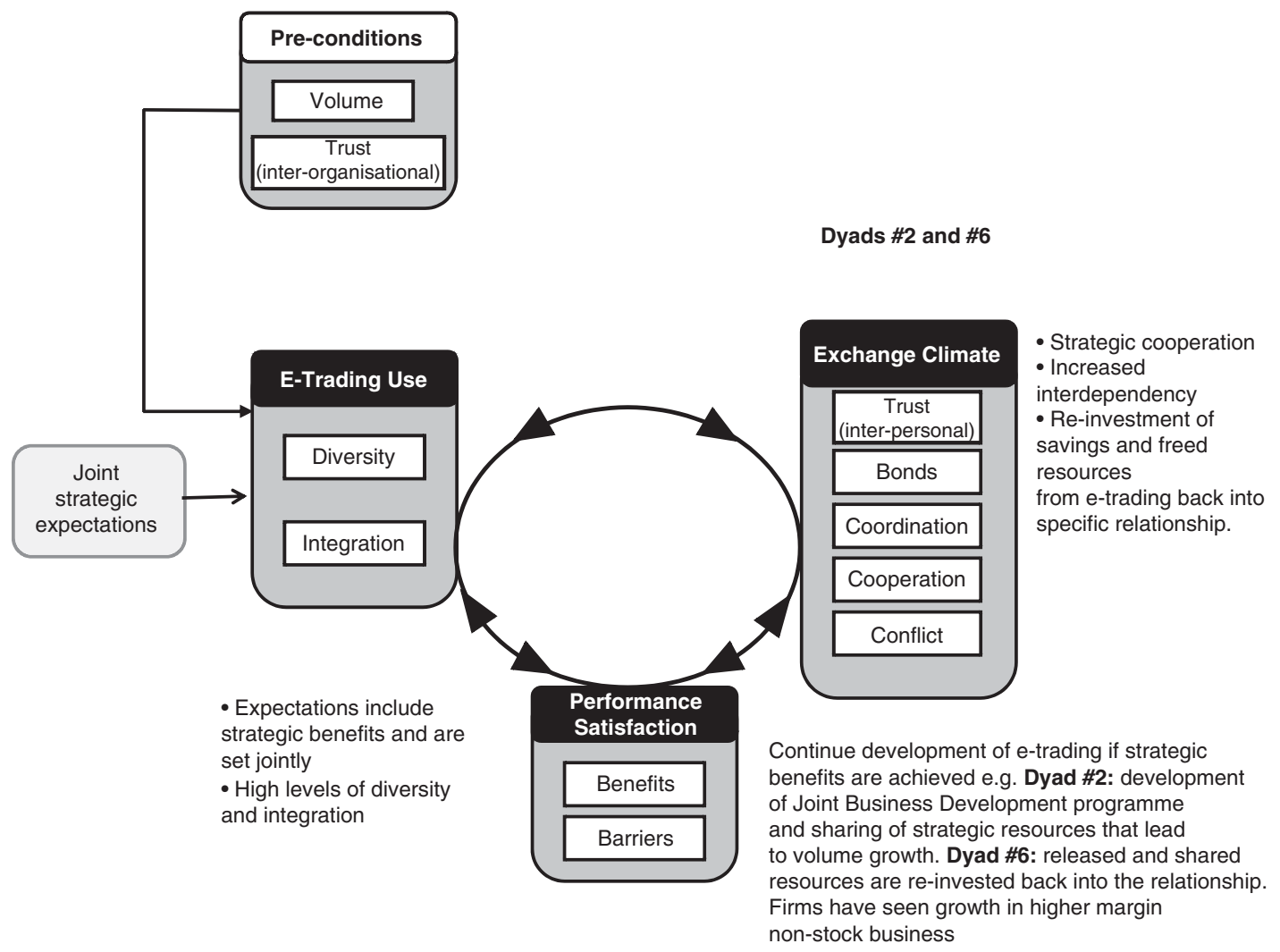

Figure 4 Strategic alliance phase. 


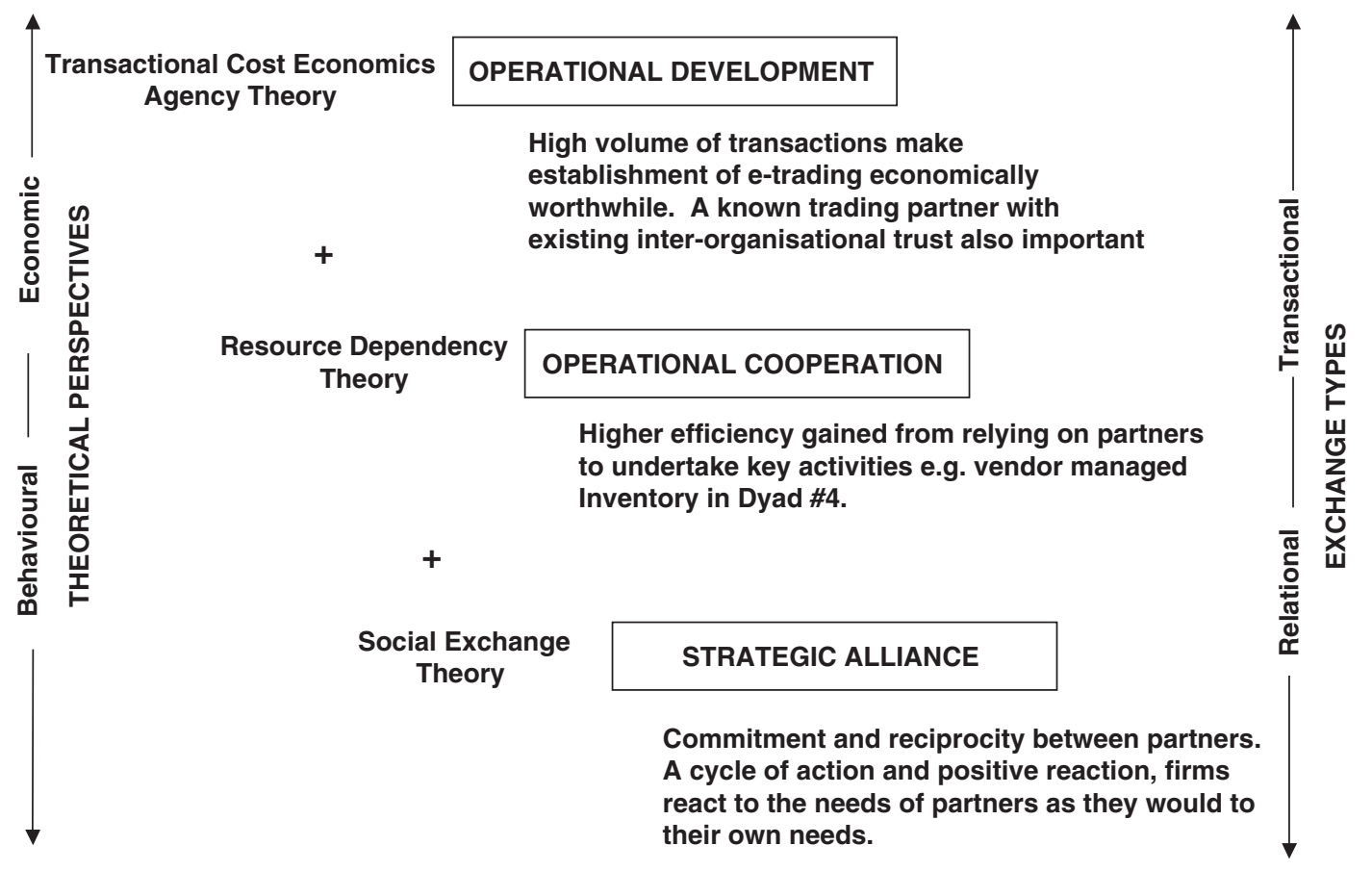

Figure 5 Combining theoretical bases.

any further development. As discussed above, moving beyond the 'Operational Development' phase requires shared investment in the technology, based on both parties' expectations of the additional benefits this will bring.

\section{Discussion}

The three phases identified appear to offer a means of addressing the call to combine the economic and behavioural theories of exchanges between firms (Dwyer et al., 1987; Barringer \& Harrison, 2000), as shown in Figure 5.

Economic efficiency arguments lead to the initial establishment and operation of an e-trading link, represented by the Operational Development phase. Consistent with the TCE perspective (Williamson, 1985), this research has shown the importance of volume of transactions as a pre-condition for the choice of e-trading partner. Agency Theory suggests consistent expectations and trust can be established with a known partner.

Behavioural themes derived from Resource Dependency Theory (Pfeffer \& Salancik, 1978) explain the Operational Cooperation phase. Companies at this phase acknowledged that higher internal efficiencies could be achieved by coordinating activities with their trading partners to perform certain tasks, such as in the case of dyad \#4, management of the buyer's inventory by the supplier.

To understand the Strategic Alliance phase additional themes from SET are needed. This phase requires commitment and reciprocity between partners (Cropanzano \& Mitchell, 2005). This is associated with relation- ships in which exchange actions are interdependent and contingent on rewarding reactions from others being the stimulus for further reaction (Blau, 1964). This continuous cycle of action and positive reaction (Kern \& Willcocks, 2000) is the basis of the development of reciprocity in which a firm reacts to the needs of its partner as it would to its own internal needs.

\section{Conclusions}

The study has combined the rational perspective of e-trading drawn from IOS studies and the relational and behavioural perspective drawn from IOR literature, by developing a framework that combines elements from both and exploring its use in six trading dyads in the European paper industry. The differences between the IOS and IOR observed across the dyads can be explained, suggesting that the structure and content of the framework are appropriate and robust. Constructs from the IOS literature appear to explain the commencement of e-trading, but constructs from the IOR literature are needed to explain both changes in the trading relationship and the further development and use of the electronic link.

The study findings show that closer strategic alignment (Allen et al., 2000), and hence the achievement of strategic benefits in addition to simple operational benefits, is dependent on all three dimensions of the proposed framework. In addition to sufficient volume, diversity and integration, inter-organisational trust and joint expectations are necessary for firms to commence e-trading. As trust between partners using e-trading grows and uncertainty about the intentions and potential 
for opportunistic behaviour by the other party decreases, 'firms and their members actively cooperate over time and assess the resulting benefits, cooperative norms of behaviour set in and become institutionalized' (Bensaou, 1997, p. 110). Performance satisfaction will be achieved if the benefits realised match expectations. A virtuous cycle is initiated enhancing the companies' sense of shared objectives, which brings trading partners closer together, allowing them to pursue further joint activities and developments.

While resources that have been freed up by e-trading can be invested in any or all relationships, the evidence from this research (dyads \#2 and \#6) shows the investment of resources, both people and funds, back into the same relationship can be particularly effective. Those dyads that have reinvested such resources within the same relationship have realised more strategic benefits than the others, including growth in sales volumes.

However, the reinvestment of freed resources into those same relationships may also represent a form of lock-in between partners. This study has shown that well-performing e-trading arrangements are relationship-specific due to the nature and role of the Exchange Climate. With increased use of standards and open technologies, exit barriers to trading arrangements are therefore less likely to arise from technology lock-in, rather they will be derived from the relationship itself.

This study considered dyads trading both via traditional EDI and via an e-marketplace. Both of the firms that remained at the first level of trading identified, the Operational Development phase were using EDI. However, the evidence from the cases suggests that it is not the technology used in an e-marketplace that leads to improved e-trading and improved IOR. It is the process of jointly working together to develop the use of the technology and new trading processes that improves the Exchange Climate between the firms.

With PaperHub you are building a solution together and dealing with problems as they arise. You need cooperation to make it succeed and contact at all levels; Board level, operations and sales and at a technical level. (Production Planning Manager in Seller 2)

This study has focussed on the paper industry, which is mature and highly consolidated, with exit barriers derived from the large capital investment requirements; relationships are well established and cannot be changed easily. These particular industry characteristics may reduce the ability to generalise the findings of this study. Further research in other industries would therefore be beneficial, either to confirm the findings of this study or to identify differences between industries.

Furthermore, the research design of this study does not allow the conclusion to be drawn that the three phases of e-trading shown in Figures 2, 3 and 4 represent a learning or maturity model. Further studies, particularly those of a longitudinal design, are required to determine if firms can commence their engagement with e-trading at any of the phases identified and if they can move between any of these phases.

An important lesson for practitioners from this work is that, although efficiency benefits can be achieved from e-trading in the short-term, strategic benefits are dependent on the way e-trading is used to influence the companies' relationship. These can only be realised if the relationship is sustained over time, and all parties continue to perceive the arrangement to be fair and beneficial. Managers should acknowledge that e-trading can be an important tool to enable and further develop inter-firm relationships with key partners but they also need to realise that exit barriers to a trading arrangement are derived from the relationship itself, due to the level of company involvement and interdependency, and not the result of investments in technology.

The study also shows that despite many companies having been reluctant to join e-marketplaces due to the belief that allowing many-to-many links would result in price comparisons and erode existing trading relationships, on the contrary, companies should actively participate in such e-marketplaces, since these can contribute to deepening and improving existing trading relationships.

\section{About the authors}

Eduardo Redondo is Professor at Universidade Lusófona de Humanidades e Tecnologias and a Consultant at GMS Consulting, Portugal. Eduardo's research interests include the influence of electronic business on market structure and on firm's marketing activities. In addition, he performs consulting work for major media and telecommunication groups in Portugal, also engaging in various industrial assignments and in professional training programmes. Eduardo holds a Ph.D. from Cranfield School of Management, U.K. E-mail: eredondo@gms.pt

Elizabeth Daniel is Professor of Information Management and Associate Dean, Research and Enterprise at the Open University Business School (OUBS), U.K. where she researches in the field of information systems in business. Prior to joining OUBS in 2005, Elizabeth worked in the IS Research Centre at Cranfield School of Management. She is the joint author, with John Ward, of the book Benefits Management: Delivering Value from IS \& IT Investments. She has published numerous papers in leading academic journals and a number of management reports. Prior to 
joining academia, she spent over 10 years in industry and continues to advise both private and public sector organisations about IS investments.

John Ward is Professor of Strategic Information Systems at Cranfield School of Management, U.K. John's main interests are the strategic uses of IS/IT and the management of IS/IT investments. He has published many papers in leading journals, including California Management Review and MIS Quarterly Executive and is co-author of the books, Strategic Planning for Information Systems and Benefits Management: Realising Value from IS and IT Investments. Prior to joining Cranfield, John worked in industry for 15 years and he now acts as a consultant to a number of major international organisations. E-mail: j.m.ward@cranfield.ac.uk

\section{References}

Allen DK, Colligan D, FinNie A and KeRn T (2000) Trust, power and interorganizational information systems: the case of the electronic trading community TransLease. Information Systems Journal 10, 21-40.

ANDERSON E and WEITZ B (1990) Determinants of continuity in conventional industrial channel dyads. Marketing Science 8, 310-323.

ANDERSON JC and NARUS JA (1990) A model of distributor firm and manufacturer firm working partnerships. Journal of Marketing 54, 42-58.

BARRETT S and KONSYNSKI BR (1982) Inter-organisational information sharing systems. MIS Quarterly 6, 93-105.

BARRINGER BR and HARRISON JS (2000) Walking a tightrope: creating value through interorganizational relationships. Journal of Management 26, 367-403.

BAZELEY P (2002) The evolution of a project involving an integrated analysis of structured qualitative and quantitative data: from N3 to NVivo. International Journal of Social Research Methodology 5, 229-243.

BENBASAT I, GOLDSTEIN DK and MEAD M (1987) The case research strategy in studies of information systems. MIS Quarterly 13, 369-386.

BENSAOU M (1997) Interorganizational cooperation: the role of information technology - an empirical comparison of U.S. and Japanese supplier relations. Information Systems Research 8, 107-124.

BLAU P (1964) Exchange and Power in Social Life. Wiley, New York.

ChATFIELD AT and YETTON P (2000) Strategic payoff from EDI as a function of EDI embeddedness. Journal of Management Information Systems 16, 195-224.

CHILES TH and MCMACKIN JF (1996) Integrating variable risk preference, trust and transaction cost economics. The Academy of Management Review 21(1), 73-99.

ChOudhuRY V, HARTZEL KS and KONSYNSKI BR (1998) Uses and consequences of electronic markets: an empirical investigation in the aircraft parts industry. MIS Quarterly 22, 471-507.

CLEMONS EK, REDDI SP and Row MC (1993) The impact of information technology on the organization of economic activity: the 'move to the middle' hypothesis. Journal of Management Information Systems 10, 9-35

COPELAND DG and MCKENNEY JL (1988) Airlines reservations systems: lessons from history. MIS Quarterly 12, 353-370.

CROPANZANO R and MITCHeLl MS (2005) Social exchange theory: an interdisciplinary review. Journal of Management 31, 874-900.

CROWLEY C, HARRé R and TAGG C (2002) Qualitative research and computing: methodological issues and practices in using QSR Nvivo and NUD*IST. International Journal of Social Research Methodology 5, 193-197.

CRUM MR, Premkumar G and Ramamurthy K (1996) An assessment of motor carrier adoption, use, and satisfaction with EDI. Transportation Journal 35, 44-57.

CUMMINGS LL and BROMLEY P (1996) The organizational trust inventory (OTI): development and validation. In Trust in Organizations: Frontiers of Theory and Research (TYLER TR and KRAMER RM, Eds), Sage Publications, Thousand Oaks, CA.

CUNNINGHAM C and TYNAN C (1993) Electronic trading, interorganizational systems and the nature of buyer-seller relationships: the need for a network perspective. International Journal of Information Management 13, 3-28.

CUNNINGHAM MT (1980) International marketing and purchasing of industrial goods - features of a European research project. European Journal of Marketing 14, 322-338.
DAI Q and KAUFFMAN RJ (2002) Business models for internet-based B2B electronic markets. International Journal of Electronic Commerce 6, 41-72.

DWYER RF, SHURR PH and OH S (1987) Developing buyer-seller relationships. Journal of Marketing 51, 11-27.

El Sawy OA, Malhotra A, Gosain S and Young KM (1999) IT-intensive value innovation in the electronic economy: insights from Marshall industries. MIS Quarterly 23, 305-333.

FEARON C and PHILIP G (1999) An empirical study of the use of EDI in supermarket chains using a new conceptual framework. Journal of Information Technology 14, 3-21.

FONTENOT RJ and WILSON EJ (1997) Relational exchange: a review of selected models for a prediction matrix of relationship activities. Journal of Business Research 39, 5-12.

FORD D (1980) The development of buyer-seller relationships in industrial markets. European Journal of Marketing 14, 339-353.

FREDRIKSSON O and VILGON M (1996) Evolution of inter-organizational information systems in industrial distribution: the cases of Luna and Pappersgruppen. European Journal of Information Systems 5, 47-61.

GALLIERS RD and LAND FF (1987) Choosing appropriate information systems research methodologies. Communications of the ACM 30, 900-902.

Gallivan MJ and DepledGe G (2003) Trust, control and the role of interorganizational systems in electronic partnerships. Information Systems Journal 13, 159-190.

HåKANSSON H (1980) Marketing strategies in industrial markets. European Journal of Marketing 14, 365-377.

HåKANSSON H and WOOTZ B (1979) A framework for industrial buying and selling. Industrial Marketing Management 8, 28-39.

HART PJ and SAUNDERS CS (1998) Emerging electronic partnerships: antecedents and dimensions of EDI use from the supplier's perspective. Journal of Management Information Systems 14, 87-111.

HEIDE JB and JOHN G (1990) Alliances in industrial purchasing: the determinants of joint action in buyer-supplier relationships. Journal of Marketing Research XXVII, 24-36.

HELPER S and MCDUfFIE JP (2003) B2B and modes of exchange: evolutionary and transformatory effects. In The Global Internet Economy (KOGAT B, Ed), Wharton Business School, U.S.A.

HOMANS GC (1958) Social behavior as exchange. American Journal of Sociology 63, 597-606.

IACOVOU CL, BENBASAT I and DEXTER AS (1995) Electronic data interchange and small organizations: adoption and impact of technology. MIS Quarterly 19, 465-485.

JAP S and MOHR JJ (2002) Leveraging internet technologies in B2B relationships. California Management Review 44, 24-38.

KALAFATIS SP (2000) Buyer-seller relationships along channels of distribution. Industrial Marketing Management 31, 215-228.

KAPLAN S and SAWHNEY M (2000) E-marketplaces: the new B2B marketplaces. Harvard Business Review 78, 97-103.

KERN T and WILLCOCKS L (2000) Exploring information technology outsourcing relationships: theory and practice. Journal of Strategic Information Systems 9, 321-350.

KUMAR N, STERN LW and ANDERSON JC (1993) Conducting interorganizational research using key informants. Academy of Management Journal 36, 1633-1651. 
KUMAR RL and CROOK CW (1999) A multi-disciplinary framework for the management of interorganizational systems. The DATA BASE for Advances in Information Systems 30, 22-37.

LEVINE S and WHITE P (1961) Exchange as a conceptual framework for the study of interorganizational relationships. Administrative Science Quarterly 5, 583-601.

LEWIN JE and JOHNSTON WJ (1997) Relationship marketing theory in practice: a case study. Journal of Business Research 39, 23-31.

MALONE TW and CROWSTON K (1994) The interdisciplinary study of coordination. ACM Computing Surveys 26, 87-119.

MALONE TW, YATES J and BENJAMIN RI (1987) Electronic markets and electronic hierarchies. Communications of the ACM 30, 484-497.

MASSETI B and ZMUD RW (1996) Measuring the extent of EDI usage in complex organizations: strategies and illustrative examples. MIS Quarterly 20, 331-345.

MAVONDO FT and RODRIGO EM (2001) The effect of relationship dimensions on interpersonal and interorganizational commitment in organizations conducting business between Australia and China. Journal of Business Research 52, 111-112.

Miles MB and HUBERMAN AM (1994) Qualitative Data Analysis: An Expanded Sourcebook 2nd edn, Sage Publications, Thousand Oaks, CA.

MORGAN RM and HUNT S (1994) The commitment-trust theory of relationship marketing. Journal of Marketing 58, 20-38.

MUKHOPADHYAY T and KEKRE S (2002) Strategic and operational benefits of electronic integration in $\mathrm{B} 2 \mathrm{~B}$ procurement processes. Management Science 48, 1301-1313.

NAKAYAMA M (2003) An assessment of EDI use and other channel communications on trading behavior and trading partner knowledge. Information \& Management 40, 563-580.

NIDUMOLU SR (1995) Interoganizational information systems and the structure and climate of buyer-supplier relationships. Information \& Management 28, 89-105.

PFEFFER J and SALANCIK GR (1978) The External Control of Organizations: A Resource Dependence Perspective. Harper \& Row Publishers, New York.
REEKERS $\mathrm{N}$ and SMITHSON S (1994) EDI in Germany and the U.K.: strategic and operational use. European Journal of Information Systems 3, 169-178.

Ross SA (1973) The economic theory of agency: the principal's problem. American Economic Review 63, 134-139.

SABHERWAL R and VIJAYASARATHY L (1994) An empirical investigation of the antecedents of telecommunication-based interorganizational systems. European Journal of Information Systems 3, 268-284.

SUOMI R (1988) Inter-organizational information systems as company resources. Information \& Management 15, 105-112.

SWATMAN PMC and SWATMAN PA (1992) EDI system integration: a definition and literature survey. The Information Society 8, 169-205.

VIJAYASARATHY LR and ROBEY D (1997) The effect of EDI on market channel relationships in retailing. Information \& Management 33, 73-86.

VLOSKY RP and WILSON EJ (1997) Partnering and traditional relationships in business marketing: an introduction to the special issue. Journal of Business Research 39, 1-4.

Walter A, Müller TA, Helfert G and Ritter T (2003) Functions of industrial supplier relationships and their impact on relationship quality. Industrial Marketing Management 32, 159-169.

WEITZ BA and JAP SD (1995) Relationship marketing and distribution channels. Journal of the Academy of Marketing Science 23, 305-320.

WILLIAMSON OE (1985) The Economic Institutions of Capitalism: Firms, Markets and Relational Contracting. The Free Press, New York.

WILSON DT (1995) An integrated model of buyer-seller relationships. Journal of the Academy of Marketing Science 23, 335-345.

WILSON DT and VLOSKY RP (1998) Interorganizational information system technology and buyer-seller relationships. Journal of Business \& Industrial Marketing 13, 215-234.

YIN RK (2003) Case Study Research; Design and Methods 3rd edn, Sage Publications, Thousand Oaks, CA.

ZAHeER A, MCEVILY B and PERRONe V (1998) Does trust matter? Exploring the effects of interorganizational and interpersonal trust on performance. Organization Science 9, 141-159. 


\section{Appendix A}

See Figure A1.

MANUFACTURERS
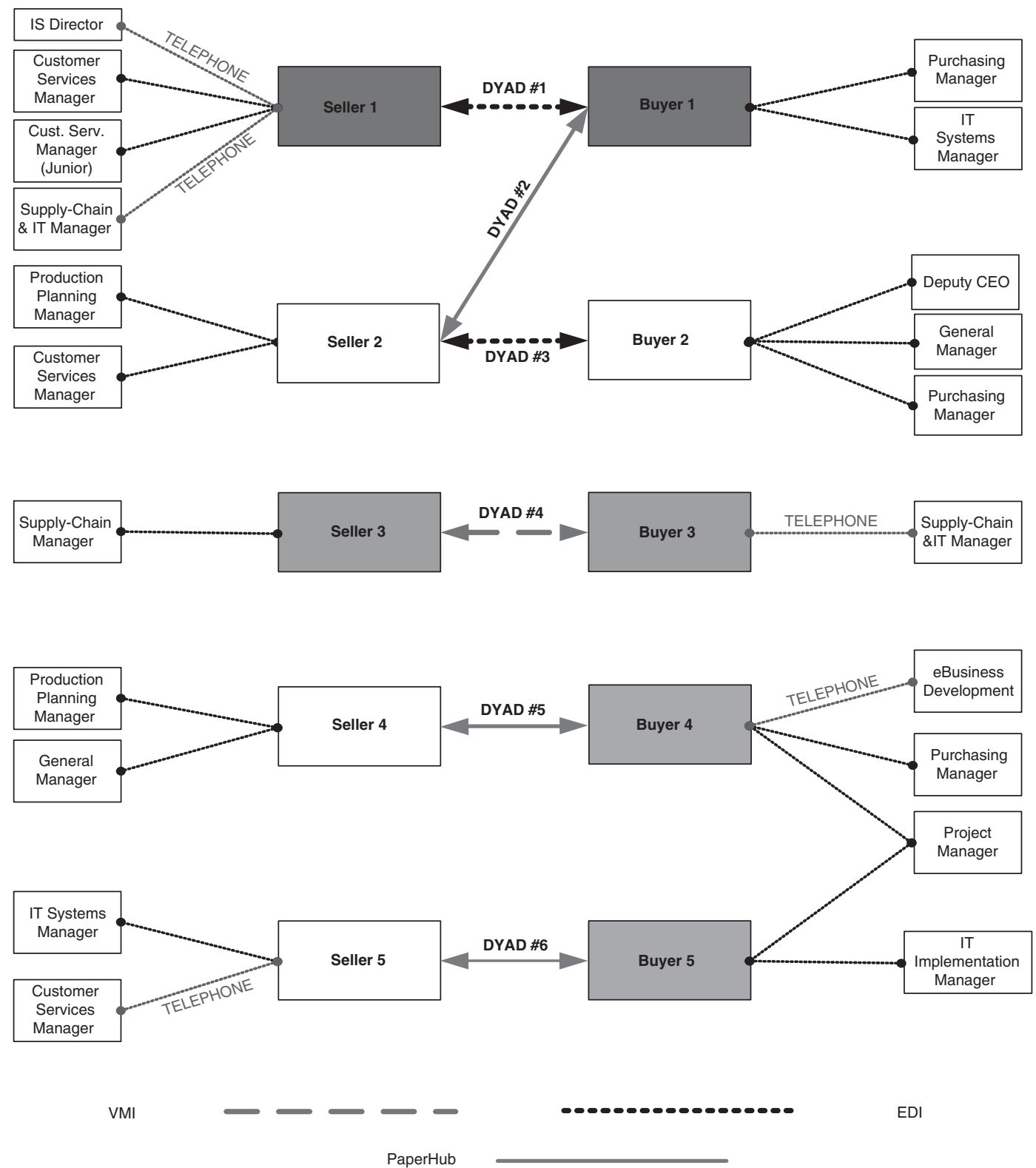

EDI

Figure A1 Dyad relationships, technology used and interviewees.

Note: Same coloured boxes represent companies belonging to the same group. 


\section{Appendix B}

See Table B1.

Table B1 Case study dyad descriptions

\begin{tabular}{|c|c|c|}
\hline Dyad \#1 (Seller 1 and Buyer 1) & Dyad \#2 (Seller 2 and Buyer 1) & Dyad \#3 (Seller 2 and Buyer 2) \\
\hline $\begin{array}{l}\text { Seller } 1 \text { is a major manufacturer of } \\
\text { technical and creative papers with a } \\
\text { presence in Europe, the Americas and } \\
\text { Asia. Buyer } 1 \text { is a worldwide distributor of } \\
\text { paper and office consumables. Although } \\
\text { both Seller } 1 \text { and Buyer } 1 \text { are owned by } \\
\text { the same parent firm, the companies } \\
\text { have been independent units for the last } \\
\text { two decades, each being responsible for } \\
\text { its own business. However, nearly 50\% } \\
\text { of Seller } 1 \text { 's business is via Buyer } 1 . \\
\text { They have been trading via EDI since } \\
1986, \text { when the electronic link was } \\
\text { initiated by Seller } 1 \text {, with messages } \\
\text { geared towards its interests of 'reducing } \\
\text { administrative costs in the supply chain } \\
\text { and integrating operations' (Supply } \\
\text { Chain and IT Director in Seller 1). }\end{array}$ & $\begin{array}{l}\text { Seller } 2 \text { is one of the largest paper } \\
\text { manufacturers in the world, employing } \\
\text { nearly } 36,000 \text { staff and has production } \\
\text { sites in } 17 \text { countries and over } 170 \text { sales } \\
\text { and distribution companies. The firms } \\
\text { were trading for over } 10 \text { years via EDI } \\
\text { before moving to PaperHub, of which } \\
\text { they were founding members, in } 2002 \text {. }\end{array}$ & $\begin{array}{l}\text { This case analysis is focussed on the } \\
\text { companies' operations in Germany. } \\
\text { Buyer } 2 \text { is among the biggest paper } \\
\text { distributors in the German market and is } \\
\text { owned by a major European paper } \\
\text { merchanting group. Although e-trading } \\
\text { is not well developed within the group, } \\
\text { Buyer } 2 \text { maintains EDI relationships with } \\
\text { some manufacturers, of which Seller } 2 \text { is } \\
\text { one of the most important. The firms } \\
\text { have been trading for } 20 \text { years and via } \\
\text { EDI since } 1996 \text {, when it was initiated by } \\
\text { Seller } 2 \text { : } \\
\text { 'In the paper distribution business prior- } \\
\text { ity is given to converting the sales force } \\
\text { from street selling to back office by } \\
\text { connecting to customers. Less impor- } \\
\text { tance is placed on connecting to suppli- } \\
\text { ers' (Deputy CEO in Buyer 2) }\end{array}$ \\
\hline
\end{tabular}

Dyad \#4 (Seller 3 and Buyer 3)

Seller 3 is one of Europe's largest

suppliers of printing, office and magazine paper and consumer packaging with 25 production units in nine countries, employing over 19,000 people. Buyer 3 is owned by Seller 3 and is one of the top five paper merchants in Europe. Over $30 \%$ of Buyer 3 sales are of Seller 3 products and, after trading via EDI since the mid-1980s they have been using PaperHub since 2002.
Dyad \#5 (Seller 4 and Buyer 4)

Seller 4 is one of the largest European producers of uncoated paper but compared with the other manufacturers studied it is relatively small. Buyer 4 is part of the largest paper distributor in Europe with $20 \%$ market share. Both firms are founder members of PaperHub through which they have been trading since 2004 .
Dyad \#6 (Seller 5 and Buyer 5)

Seller 5 is one of the world's largest producers of coated fine paper, which represents $81 \%$ of the group sales. It has production facilities on three continents and employs over 16,000 people. Buyer 5 is a leading paper merchant in the U.K. and is part of the same merchanting group as Buyer 4. The two firms have traded via EDI since the early 1990s and moved to PaperHub in 2002.

\section{Appendix C}

A number of e-marketplaces emerged in the paper industry, such as PaperHub and ForestExpress. For example, PaperHub was developed as a joint venture of paper producers and merchants, which can be understood as a consortium marketplace. PaperHub was intended as an electronic platform which every participant in the paper industry could join, with the aim of supporting systematic sourcing between companies. PaperHub was developed as a standardised platform based on PapiNet standard messages and intended for many-to-many type relationships.

PapiNet is a strategic alliance formed between some of Europe's major paper producers, the Confederation of European Paper Industries and the American Forest \&
Paper Association, among other important organisations. PapiNet standards were created as open standards to facilitate the trading procedures in the paper industry and overcome some of the limitations associated with EDI. As in other cases (Chatfield \& Yetton, 2000), although EDIPAP standards had been developed and employed in the paper industry for a number of years, when establishing an EDI link to their partners companies simply automated existing information flows and decision processes, maintaining their internal processes. As a consequence, in many cases a company had to manually change product codes when trading electronically with two different partners. This resulted in important limitations to 

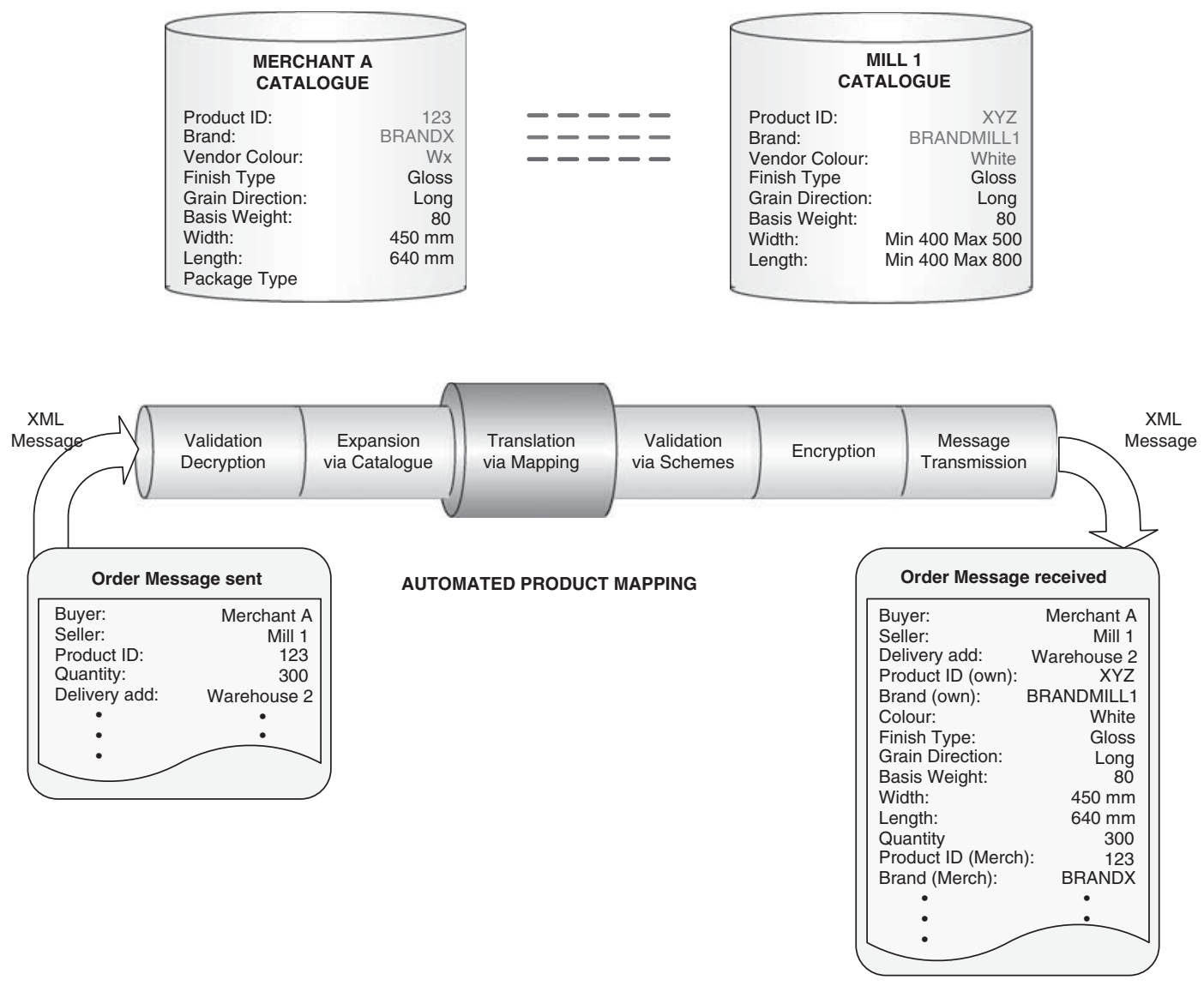

Figure C1 Product translation.

trading with multiple partners through e-marketplaces.

A variety of services were offered by PaperHub, from product catalogue, to product code translation and supply-chain visibility. The product translation functionality was created to enable the match between the unique product attribute of one company with the product attribute values of its various trading partners, finding the corresponding product based on each company's individual descriptions. Thus, the product translation functionality allows companies to trade with multiple partners without any manual intervention (see Figure C1). 